\title{
VILLAGES WITH FORTIFIED CHURCHES IN TRANSYLVANIA: ARCHITECTURE, HISTORY AND INTANGIBLE CULTURE
}

\author{
V. Cristini ${ }^{1, *}$, L. García-Soriano ${ }^{1}$, F. Vegas ${ }^{1}$ \\ ${ }^{1}$ Research Centre PEGASO, Universitat Politècnica de València, Valencia, Spain - (vacri, fvegas)@cpa.upv.es, \\ ligarso@upv.es
}

Commission II - WG II/8

KEY WORDS: Middle Age architecture, Conservation strategies, UNESCO World Heritage Site

\begin{abstract}
:
Romania's significant German (Saxon) heritage is perfectly conserved in southern Transylvania, where Saxons arrived in the mid1100s from the Rhine and Moselle river regions. Highly respected for their skill and talent, this population succeeded in gaining administrative autonomy, a feat practically unrivalled through a feudal Europe of absolute monarchies. The result of almost nine centuries of existence of the Saxon (German) community in southern Transylvania is still visible today in a stunning melting pot of cultural and architectural heritage, unique in Europe. Within the framework of the project " $3 \mathrm{~d}$ Past, Living \& virtual visiting European World Heritage" the set of 7 villages (Biertan, Câlnic, Dârjiu, Prejmer, Saschiz, Valea Viilor, Viscri) listed by UNESCO since 1993, have been studied in detail. Strategies for maintenance and conservation have been analysed in order to contribute to the awareness and preservation of the principles of authenticity and integrity of those sites.
\end{abstract}

\section{THE 3D-PAST PROJECT}

\subsection{General project framework}

The Universities of UNIFI (Italy) and UPV (Spain) are participants in the project "3D past, living \& virtual visiting European World Heritage" led by ESG School of Portugal, with support from Creative Europe (2016-2020, Figure 1). This project focuses on the vernacular settlements located in different sites across Europe and it explores the architectural parameters relating to the buildings' maintenance, in order to contribute to the awareness and preservation of the principles of authenticity and integrity at these sites.

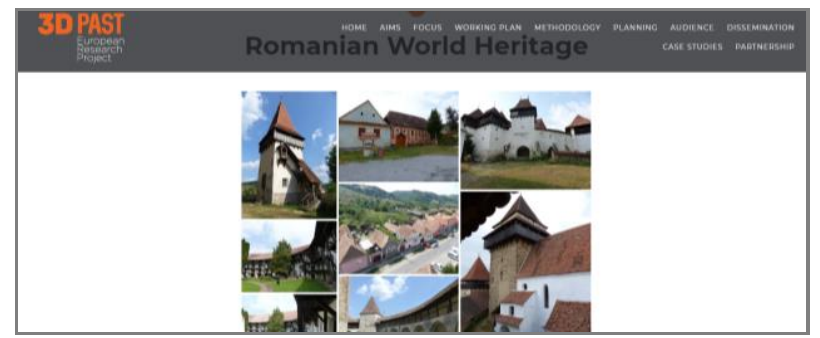

Figure 1. Project details from https://esg.pt/3dpast/.

Moreover, it also contributes to the interpretation of the local building culture, the historical evolution of the sites of the dwellings, recreated through $3 \mathrm{D}$ visualization and augmented reality. This could become a powerful didactic tool for the general public (children, young people and any interested citizens, etc.), not only to learn and value the relevance of the vernacular buildings to be preserved, but also to enhance the intangible culture still in use today and its buildings' architectural techniques, materials, and maintenance of building systems. A legacy passed down from generation to generation, essential to their survival as part of the European identity (extract by https://esg.pt/3dpast/).
The project also aims to attract tourists to these sites, through the use of on-site Mobile Apps, which will enlighten as to different ways of inhabiting, as well as to new audiences. Furthermore, this will allow non-traveller citizens to visit other dimensions, such as the 3D modelling of World Heritage Sites in Europe (Correia et al., 2016).

In this framework eight World Heritage Sites from different geographical locations in Europe are addressed. Each site is located in a different country. Seven in the European Union, while one (Georgia) is located in the geographical area of the Council of Europe. In geographical terms, all the sites selected represent unique contexts within the European territory, from the north (Finland), centre (Czech Republic), southeast (Greece), southwest (Spain), and from east (Georgia) to west (Portugal). Economically deprived regions are also addressed, such as Pico in the Atlantic Azores islands (Portugal), and Transylvania (Romania). This text presents recent outcomes relating to this last case study, examining the villages with fortified churches in Rumania (Figure 2), studied by the team from UPV.

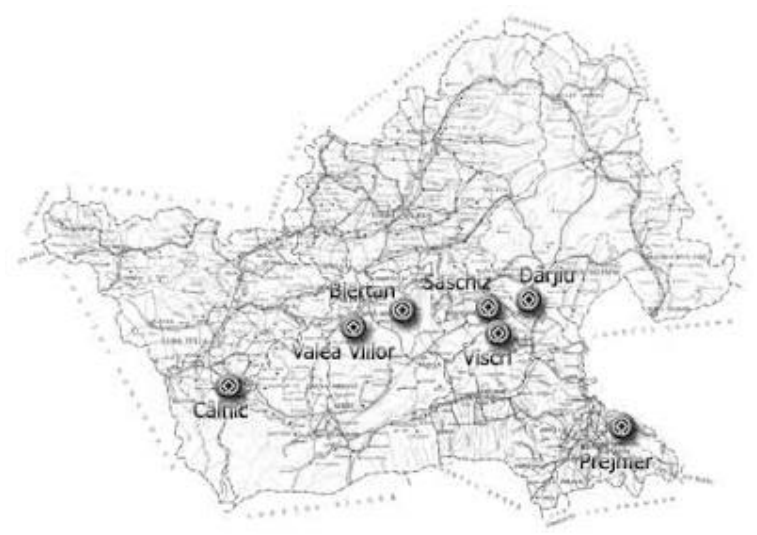

Figure 2. Enclaves listed by UNESCO in Transylvania (Unesco).

\footnotetext{
* Corresponding author
} 


\subsection{Transylvania and its Saxon past}

Romania's significant German (Saxon) heritage is basically present in southern Transylvania, home to hundreds of wellpreserved Saxon towns and villages. The Saxons came to Transylvania in the mid-1100s from the nearby regions of the Rhine and Moselle rivers. Highly respected for their skill and talent, they succeeded in gaining administrative autonomy, almost unmatched throughout a feudal Europe of absolute monarchies. The result of almost nine centuries of existence of the Saxon (German) community in southern Transylvania is a cultural and architectural heritage that is unique in Europe. Transylvania is home to hundreds of towns and fortified churches built by Saxons between the 13th and 15th centuries. This heritage is still visible and is part of the Romanian cultural DNA even to the present day (Philippi, 2016).

The Saxon colonization of Transylvania basically began with King Geza II of Hungary (1141-1162). For many decades the main task of German settlers was to defend the southeast border of the kingdom of Hungary. This colonization continued until the late 13th century. Although most of the colonists came from the Holy Roman Empire and generally spoke Franconian dialects (German) they became known as Saxons in the Hungarian chancellery.

The Saxon population in Transylvania has fallen sharply since the Second World War. Despite mass migration, mostly to Germany, they still form a considerable minority within the country (Figure 3 ), where they coexist with a second small gypsy minority.

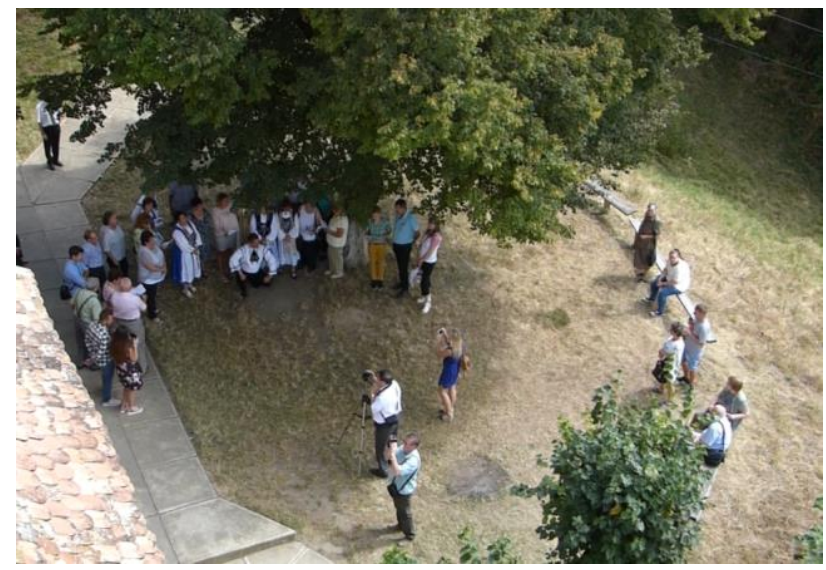

Figure 3. Saxon people singing a celebrating song in front of Alma Vii Fortified Church.

\subsection{The architectural heritage of the Saxon legacy}

The Saxons populated the borders of what is currently Transylvania, hoping to resist invasions, first from the Mongols and then from the Ottomans. One of the strategic solutions used for this was the fortification of village churches, which made it possible to protect the entire community when faced with an imminent attack (Tiplic, 2006).

At present, some of these churches barely have an outer wall to protect them while others are still veritable mediaeval fortresses with defensive towers and impressive outer walls (Duguleana, Postelnicu, 2018). This is why, in Transylvania and especially in the outskirts of Sibiu, the centre of the Saxon Community, seven of the forty churches which can be found were declared World Heritage sites by UNESCO in 1993: Biertan, Câlnic, Darjiu, Prejmer, Saschiz, Valea, Viilor Viscri.
Accordingly, interest in these complexes is not limited exclusively to the constructive, architectural, and documentary value of religious buildings, but is also about a global vision of the villages, prompting a reflection which incorporates domestic and residential architecture, linked to this centuries-old past which offers a characteristic marriage of culture and ethnicity.

\section{CHARACTERISTICS OF THE VILLAGES OF TRANSYLVANIA}

\subsection{Seven enclaves for understanding the intercultural past of Transylvania}

Among the 250 Saxon villages still existing in Transylvania nowadays, the seven monumental enclaves listed by UNESCO in Transylvania should be briefly mentioned in order to understand the objectives of the 3D Past project. This in turn makes it possible to assess the rich constructions of the villages in great detail, linked to domestic and residential architecture.

The Saxon lands of southern Transylvania lie mostly within the area delimited by the medieval fortress-towns of Sibiu, Sighisoara and Brasov. This is one of Europe's least known examples of remarkable - authentic - cultural survival of medieval landscape: fortified churches, unspoilt villages, and non-intensive mixed farming in ecological balance with nature and wildlife, found amongst mature woodland and haymeadows full of wildflowers (Akeroyd, 2006).

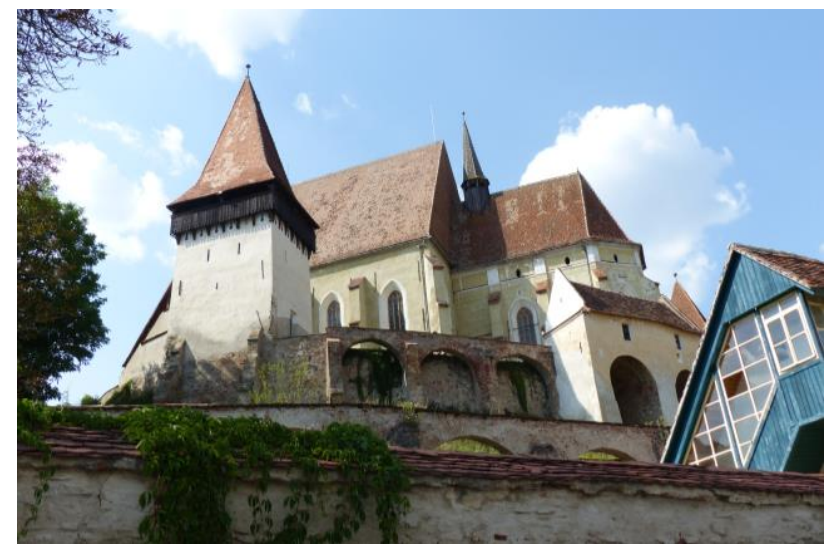

Figure 4. Biertan Fortified Church.

Biertan (Figure 4) was an ancient medieval city that became a town in the 16th century. Competing with nearby Mosna and Medias for control over the See, locals decided to build a huge church on the location of an existing one, right in the village centre. This was not an unusual practice, the villagers from Saschiz chose the same strategy when they were competing with nearby Sighisoara, and thanks to this an enormous church was built.

In contrast, Câlnic church (Figure 5) was built as a private residence sometime in the 13th century by the aristocrat Chyl de Kelling, so that initially this Câlnic monument was a small castle. This site remained in the hands of the family until 1430, when it was purchased by villagers who transformed it into a proper fortification to save their lives during the numerous raids from armies.

Darjiu fortified church was also initially built in the Romanesque style, and later rebuilt in the Gothic style. It was fortified in the 16th century when locals drew inspiration from the fortified churches of neighbouring Saxon villages. 


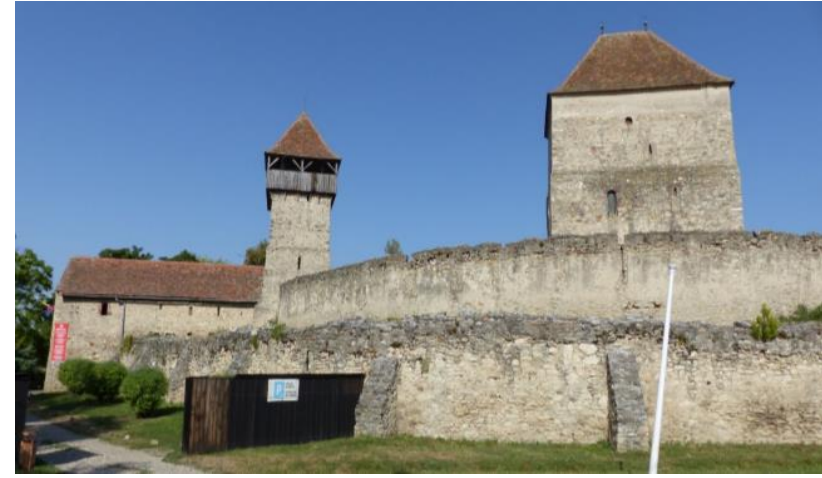

Figure 5. Defensive system of Câlnic Fortified Church.

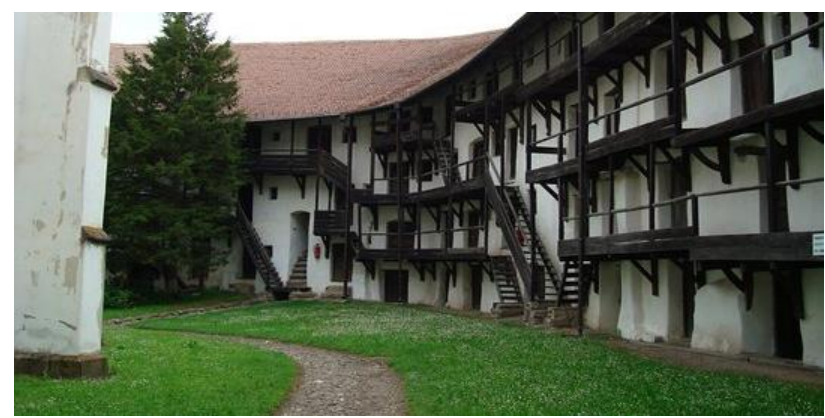

Figure 6. Details of Prejmer fortified church.

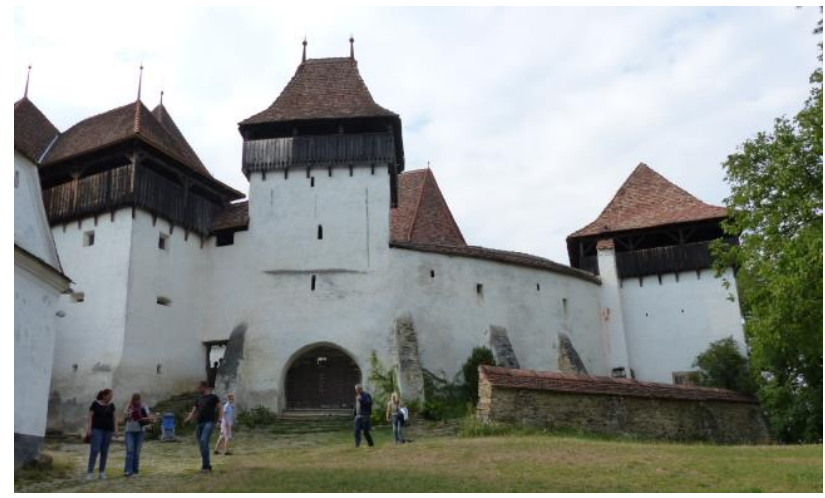

Figure 7. Viscri fortified church.

Furthermore, Prejmer (Figure 6), built by Teutonic knights in 1212-1213, is currently considered the largest fortified church in southeast Europe and was famous as a great defensive system.

Saschiz is renowned not only as home to one of Transylvania's finest fortified churches but also as a major hub of carpentry and wood-painting. It was here that Saschiz blue pottery was born in 1702. In this case the Evangelical Church of Saschiz was built between 1493 and 1496 by Saxon colonists. The monument is still very impressive for its sheer size and the way in which the fortifying elements have been adapted to the shape of a church building.

The Valea Viilor complex is located in the so-called Vineyards Valley. This fortified church was built in 1263 in the Gothic style and was expanded and fortified in the 15th and 16th centuries by adding a series of walls 26 feet tall and five feet wide. A unique element is the well in the centre of the church choir which provided water for the locals during sieges.
Finally, Viscri church (Figure 7) was built around 1100 by the Szekler population and taken over by Saxon colonists in 1185 . This explains why this unique Gothic church displays a plain straight ceiling rather than a traditional vaulted one. In the 14th century, the eastern section was rebuilt, and the first fortification walls with towers were added around 1525 (Corsale, Ionio, 2014).

\subsection{Monumental architecture \& residential architecture}

It is true that the monuments of the seven villages listed by UNESCO are amazingly well-preserved. However, they all stand out for a very special residential and domestic fabric, covering the urban and territorial scale as well as that of architecture and detail (Figure 8). A series of urban nuclei rich in constructive features and with a strong cultural identity have gradually formed around the seven major fortified churches, which the 3D Past project aims to publicize as a whole.

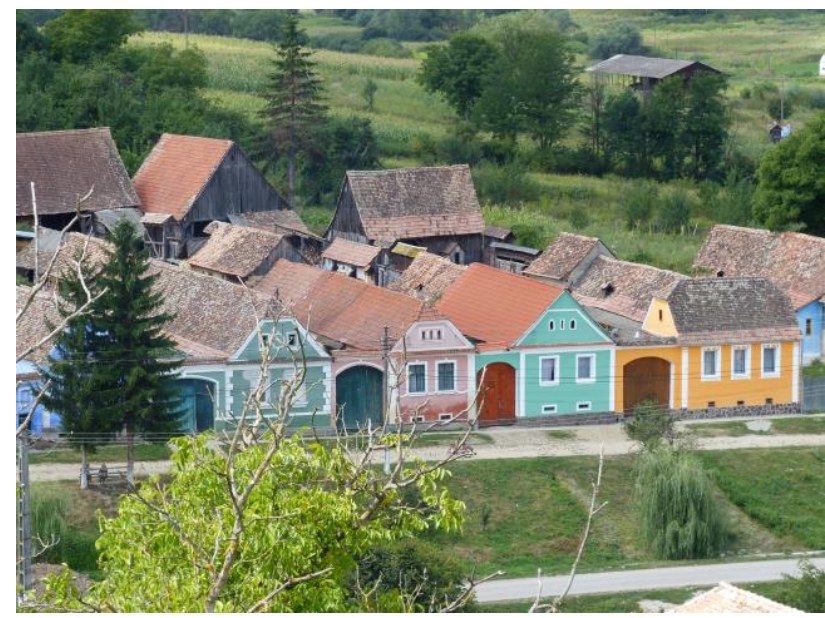

Figure 8. Dwellings in the main street of Viscri.

The villages which have been developed by the Saxons tend to rotate around the central nucleus (fortified church) and its defence systems. Despite this central hub, the development of the urban nucleus is not radial but linear and is structured by main streets whose point of reference is the church and/or other nearby public buildings, such as the Council Hall or school (Szaktilla, 2008). Streams and rivers also affect the possible orientation of streets, which follow straight plots affected to varying degrees by these natural features. This is the case of Viscri (Figure 9) or Biertan, villages structured on either side of the water line.

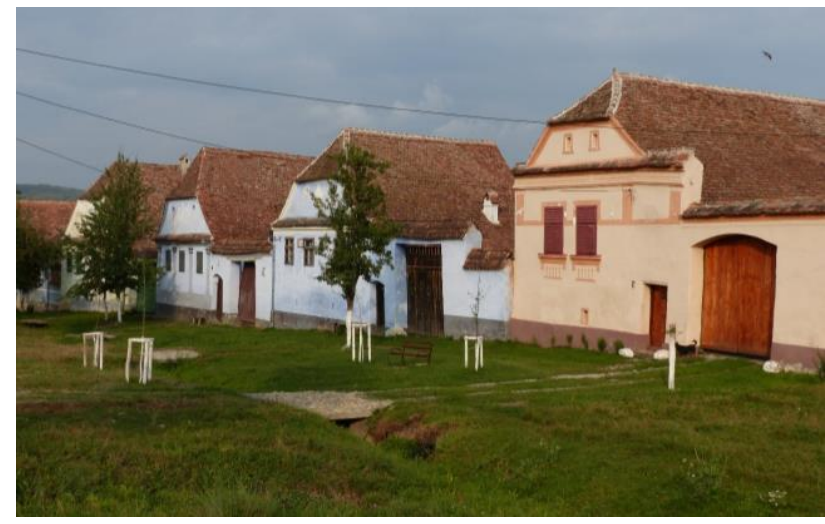

Figure 9. Dwellings in the main street of Viscri. 
Perhaps one of the most distinctive characteristics of these inhabited nuclei is that the residential plots are fully regular and rhythmic, with adjoining housing following the same typology and spatial interpretation, barely distinguishable by rendering and finish in historic terms (Figure 10).

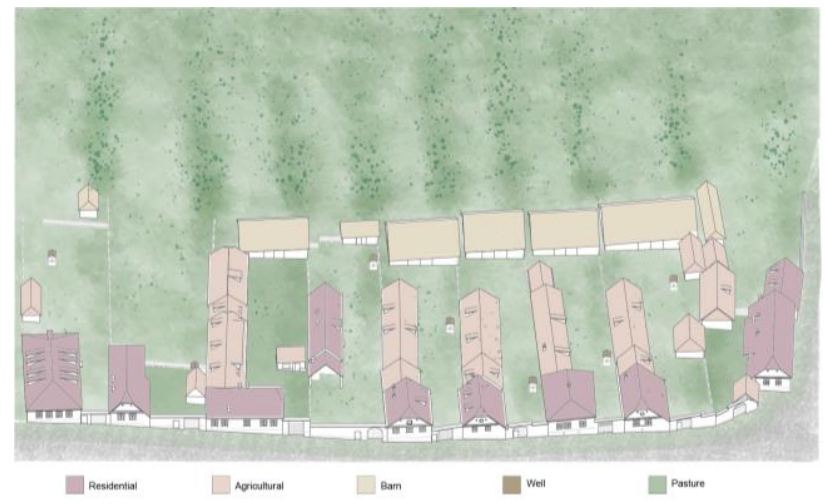

Figure 10. Sequence of residential buildings in the village of Viscri.

\section{3 "Typical" housing and its use}

The residential buildings of the Saxon villages of Transylvania are decidedly rural, and the domestic space is organized based on a close relationship with agricultural production and crop cycles (Fabini, 2015).

The typical dwelling (Figure 11) was situated at the end of each plot, overlooking the street with an entrance which delimits and closes off the property. The internal courtyard, separated by the main door, is elongated and shows a clear "introverted" sequence of spaces, usually always divided into five major areas. The first strip of the plot is occupied by the family home or residential nucleus in the strictest sense. This is followed by a second space, a threshing floor with an oven, summer kitchen and other service areas. The next part is a yard which is usually occupied by a small stable and/or chicken coop, and also includes a lavatory. The fourth space is normally composed of storage buildings and stores for the family's seasonal crops (grain, hay....), while, the fifth section is located at the back, with an orchard and garden.

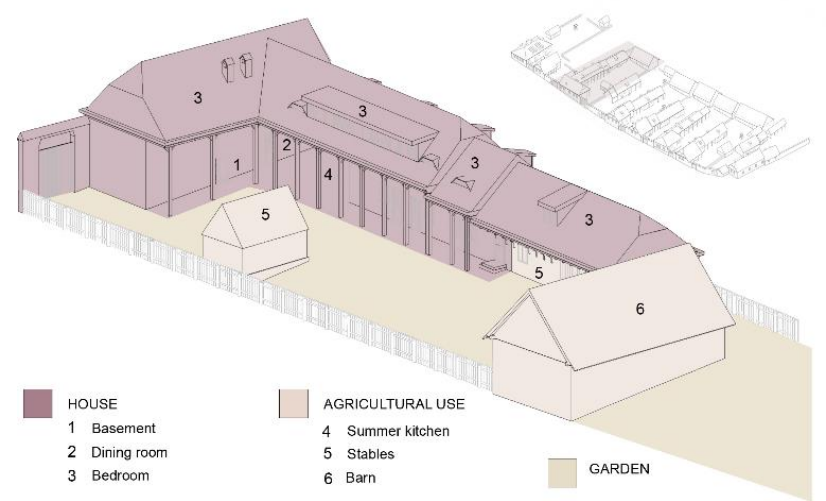

Figure 11. Graphical reconstruction of a typical dwelling in the village of Viscri.

The residential building (Figure 12), located in the first part of the plot is accessed from the courtyard and is the only part of the volume "open" to the village (on its decorated façade). The building has a partly underground space, a vaulted cellar, with strong load-bearing walls in brick or masonry. The upper level, slightly raised from the ground, is dedicated to use as a living room, kitchen, and bedrooms, usually protected by an oak roof (Wilkie, 2001).

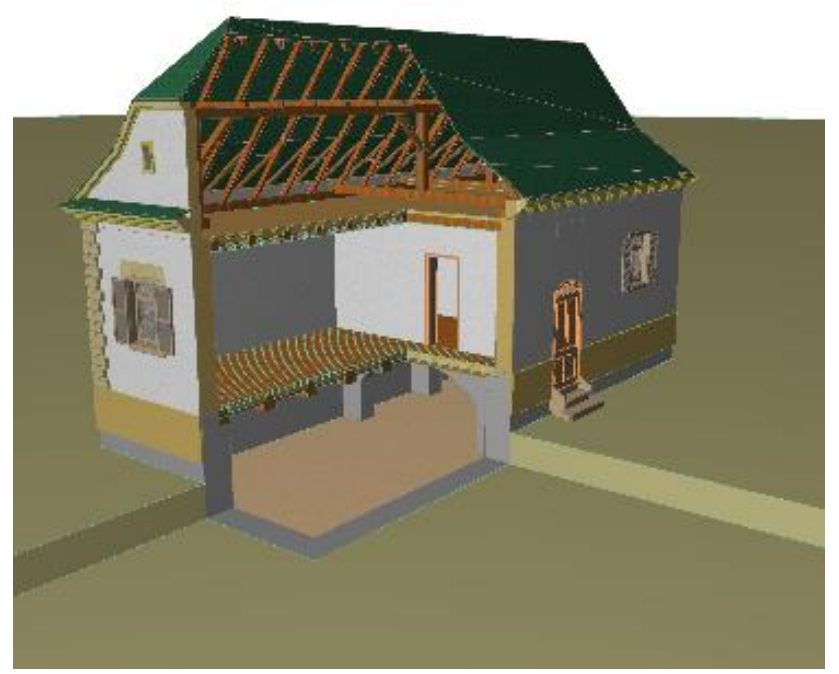

Figure 12. Graphical reconstruction of the residential building of a typical dwelling in the village of Viscri.

\section{THE VILLAGE MANAGEMENT PLAN}

The villages with fortified churches were recognised by UNESCO in 1993, experiencing a progressive transition before being awarded protected status when a Management Plan, was drawn up by the Ministry of Culture of Romania in 2013, and revised in 2014 (https://whc.unesco.org/en/list/596/documents/). During this period, many of the constructive and typological features of the villages, especially the privately owned residential buildings, were greatly altered. In addition to the replacement of floors, roofs, beams or joinery in these, many other unsuitable interventions have been carried out, altering the historic sector, demolishing agricultural annexes or adding new volumes to courtyards.

\subsection{The management plan: some details}

The 2013 management plan incorporated some graphic, historical and legislative sections, as well as maps to a scale of 1:5000 of the relevant locations (Figure 13). Following a painstaking inventory of the buildings, a "protected" area and a buffer zone were outlined to prevent an uncontrolled expansion or urbanistic changes prompted by tourism or real estate speculation. This protection measure is also useful for monitoring over time, in order to understand how these villages have developed and grown and what conservation policies were followed.

The plan follows four basic lines of action: some more spread out in time (still in place to date, as observed in the data collection processes for 3D Past) and other more occasional ones with a shorter duration.

The first is the programme for "Buildings in need of urgent intervention", which is supported by periodic reports from specialist inspectors in charge of updating and revising the inventory of the classified buildings, considering different factors to support possible subsidies (AA.VV., 2006). Buildings 
are analysed in the programme based on several items. These include the type of building (dwelling or agricultural annex), degree of occupation, damage observed, uses, information on the owners, historic report of interventions... There are very few Saxons left still living in Transylvania today: their sudden emigration in the late 20th century resulted in a large number of empty houses, causing major problems due to their lack of maintenance, and today these are basically the object of "nostalgic tourism" by German-Hungarian people.

In fact, very recently the Saxon heritage also suffered the trauma of a totalitarian and oppressive state, which has contributed to altering people's pride in their origins in the countryside, and traditional rural knowledge and roots (Gherman, 2019).

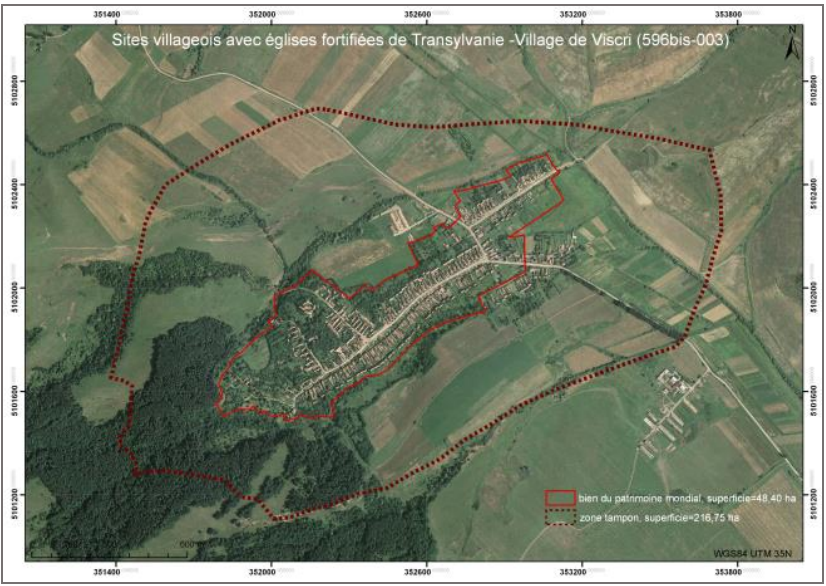

Figure 13. Unesco protected area and buffer zone- Viscri case study (Unesco).

Attempts have been made to limit the gradual obsolescence of these villages through the programme of "Buildings for reuse", which periodically drafts reports and carries out inspections, in collaboration with local authorities and under the supervision of the Transylvania Trust (http://www.transylvaniatrust.ro/\#).

This action aimed to seek solutions to bring these buildings up to contemporary housing standards (Figure 14), without decontextualizing or drastically altering their structure (volumes, accesses, openings...), their historical planimetry and/or constructive features (roofs, floors, joinery...).

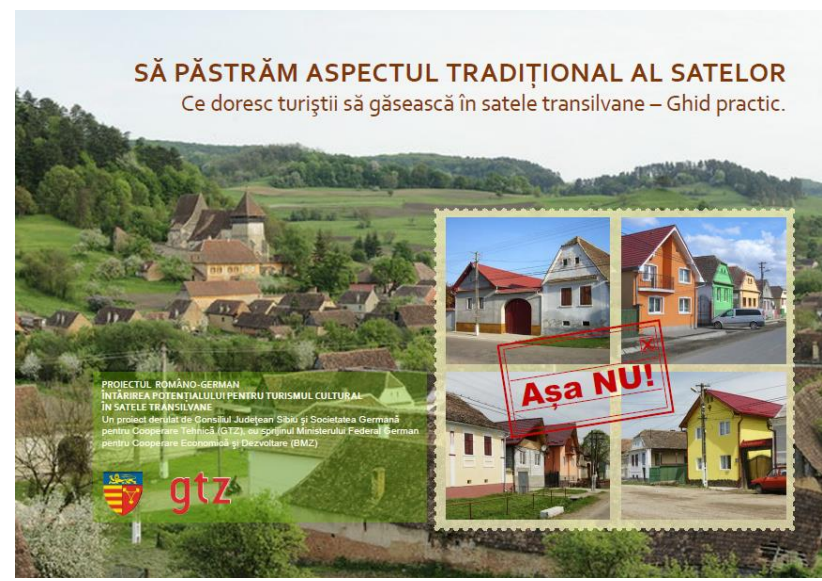

Figure 14. Examples of inappropriate actions stressed by management plan.
Another programme worth noting is the project "Protect know how from oblivion", carried out in collaboration with Rumania Nostra and several local and supraterritorial institutions.

In this case the objective of the programme is to promote and formalize resources relating to the place of origin of local materials, traditional processing forms, and specific autochthonous construction processes.

For this, a major point within the programme is to set up teams of craftsmen, training them to guarantee a long-term transmission of specific types of constructive and artisanal know how connected to the architecture of these villages.

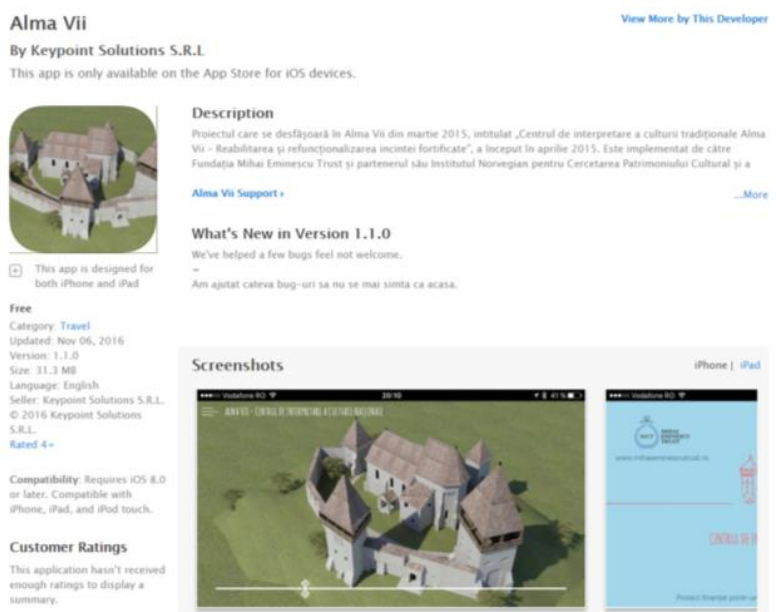

Figure 15. App-example of promoting resource, Alma Vii village.

Finally, the programme "Education for understanding and protection" which covers different collectives (specialists, local administration, citizens, students, owners...) is also worthy of mention (Figure 15). The aim of this programme is to inform and raise awareness (in the short-mid-long term) among the different agents involved in the amazing vitality of the historic villages and their fortified churches, covering important social and ethnic issues, as well as "technical" ones.
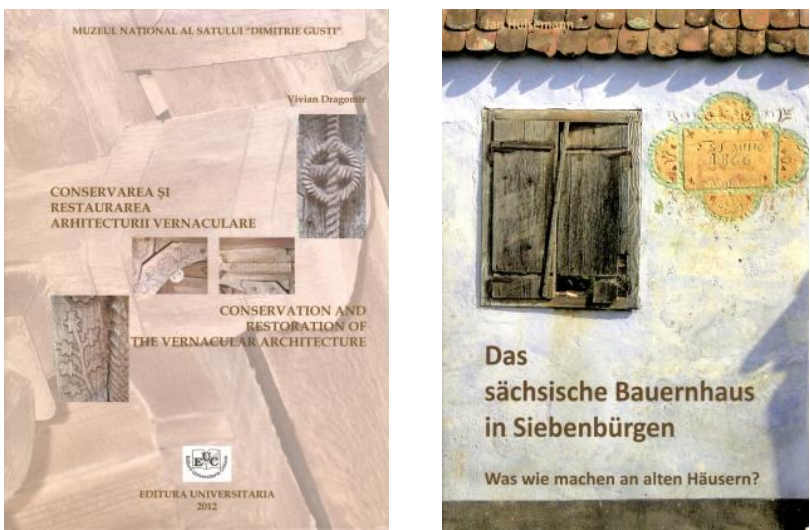

Figure 16. examples of publications driving forces for local development.

All this contributes to promoting resources (Figure 16), clearly identifying respectful or inappropriate actions, thus generating possible driving forces for local development while bearing in mind possible ethnic or social differences (Gabor et al., 2013; Iosif, 2011). 


\section{CONCLUSIONS}

In this research, the 3D Past project has stressed the importance of sharing vernacular architecture qualities and the intangible local know-how to preserve the authentic fabric in Transylvanian villages with fortified churches, as shown by the authors of the text. Some of the project's objectives stress the importance of exploring the inhabited heritage experience through different dimensions, interconnecting architecture, history, and intangible culture in a trans-disciplinary way. The early results for 3D Past have shown the importance of bringing to light vernacular and traditional know-how for the new generations enhancing the intangible building culture of WHS in Europe. This would take into consideration cultural and social factors like wealth k-factors, as demonstrated in the case study of Transylvanian villages with their minorities.

\section{ACKNOWLEDGEMENTS}

This paper is the result of the research project 3D Past - "Living \& virtual visiting European World Heritage" [Grant Agreement Ref No570729-CREA-1-2016-1-PT-CULT-COOP1], which was co-funded by the European Union, under the programme Creative Europe (2016-2020).

\section{REFERENCES}

AA.VV., 2006: Safeguarding the Saxon Heritage in Transylvania. The PREM project final report, Riksantikvaren ed., Norway; https://ra.brage.unit.no/raxmlui/bitstream/handle/11250/175631/nypan_saxon_heritage.p df? sequence $=1$ (consulted on January 2020)

Akeroy, J., 2006: The Historic Countryside of the Saxon Villages of Southern Transylvania, Fundatia Adept Ed., Mures

Correia, M. et al., 2016: Memory of 3D Past Project, unpublished, ESG, Portugal

Corsale, A., Ionio, M., 2014, "Transylvanian Saxon culture as heritage: Insights from Viscri, Romania" in Geoforum 52, n²223, Elseiver, Amsterdam

https://whc.unesco.org/en/list/596/documents/ file:///C:/Users/PC/Downloads/596bis-ICOMOS-705-en.pdf (consulted on January 2020)

http://www.transylvaniatrust.ro/\# (consulted on January 2020)

https://esg.pt/3dpast/(consulted on January 2020)

http://www.eheritage.org/category/repository/ (Consulte on Januray 2020)

https://fundatia-adept.org/ (consulted on January 2020)

Duguleana, M., Postelnicu, C.C., 2018: "Towards Preserving Transylvanian Fortified Churches" in Virtual Reality in International Conference on VR Technologies in Cultural Heritage, VRTCH n. 34-45, Springer, Cham, https://doi.org/10.1007/978-3-030-05819-7_4

Fabini, H., 2015: The Church-fortresses of the Transylvanan Saxons. Sibiu: MonuMenta
Gabor, D.I., et al., 2013: "Possibilities for rural tourism development around fortified churches". In Lucrări Științifice Manag. Agricol 15(4), n.259, Rumania

Gherman, C., 2019, The Saxoncountry houses in Transylvania,; final degree work, unpublished, Lund University, Sweden

Iosif, D., 2011, "Ecotourism as a community industry: case study; Transylvanian Saxon communities with fortified

Churches". In Cinq Continents, 1(1), 17-28. https://nbnresolving.org/urn:nbn:de:0168-ssoar-290341 (consulted on January 2020)

Philippi, P., 2016: Transylvania: short Historty of the Region...; Shiller Publishing House, Hungary

Szaktilla, S., 2008: "The spirit of the transilvanian fortified churches..." in COMOS General Assembly and International Symposium, 'Finding the spirit of place, between the tangible and the intangible', Quebec, https://openarchive.icomos.org (consulted on January 2020)

Tiplic, I.M.,2006: Fortified churches of Transylvanian Saxons, Noi Media print, Rumenia

Wilkie, K., 2001, The Saxon villages of Transylvania, Romania Richmond-upon-Thames, UK 